\title{
PERSISTENT INEQUALITIES \\ Women and Electoral Politics \\ in the Zimbabwe Elections in 2005
}

\author{
By
Bertha Chiroro
}

Bertha Chiroro is a Kellogg Foundation PhD Fellow and a Researcher at EISA PO Box 740 Auckland Park 2006, Johannesburg, South Africa

Tel: +27(0)11 482 5495; Fax:+27(0)11 4826163

e-mail: bertha@eisa.org.za

\begin{abstract}
This paper examines the 2005 elections in Zimbabwe in the context of persistent gender inequalities that have existed since 1980. These inequalities have been exacerbated by an entrenched patriarchal culture and an electoral system that neither facilitates nor adds value to the increased representation and participation of women. The 31 March 2005 parliamentary elections in Zimbabwe were held amid profound struggles and disagreements over how best to change the formal political machinery. At the same time, struggles by the opposition to broaden and deepen political, economic and civil rights had intensified. Within this same struggle for democratisation the women's movement has defined itselfby a liberal human rightsbased agenda and has waged the struggle at two levels. The first is the level of a feminist consciousness, where women have fought a war against patriarchy since 1980, through a critique of discriminatory legislation and demands for committed measures to increase women's political representation. The second is at the oppositional level, where some women's groups in alliance with other civil society organisations and opposition political parties have challenged the state and the legitimacy of the ZANU-PF rulers and the lack of a free participatory environment. A reflection on the results of the 2005 elections shows that women have not won these two battles. Patriarchy still remains entrenched in political institutions and political parties. A culture that uncritically accepts the need for women as political leaders does not exist. The under representation of women in Zimbabwe has been so stark since 1980 that the injustice seems beyond question. When women occupy a mere 16 per cent of the seats in Parliament, it should be clear that there is something unsatisfactory in the current political arrangements or in the electoral system.
\end{abstract}

\section{INTRODUCTION}

Since independence in 1980 women in Zimbabwe have consistently engaged the state in two ways: through strategy and critique and the mobilisation and growth 
of an autonomous feminist movement. The feminist movement has also pushed for a significant presence for women within political parties and state institutions. It has been a hard road of experimentation with different strategies of mobilisation and state penetration. However, the inequalities persist and are reflected more clearly in the legislature.

On 31 March 2005 Zimbabwe held its sixth legislative elections since independence. Much attention was focused on whether the elections would be free and fair and on Zimbabwe's compliance or non-compliance with the Southern African Development Community (SADC) guidelines governing democratic elections, signed at the SADC summit in Mauritius in 2004. The guidelines are silent on specific measures that should be implemented by states to ensure the increased participation and representation of women. In the list of guidelines women are mentioned only once, and are lumped together with the disabled and the youth. The responsible government is only asked to encourage the participation of disadvantaged groups.

During the election campaign little was said about women's participation in politics, and gender issues and women's concerns were not central to the campaign. Social and political issues were more paramount and the struggle for survival was so crucial that gender issues took a back seat to issues such as land, the economy and the perceived imperialist threat by the opposition in alliance with Western countries. The women in Zimbabwe had wanted a quota at the legislative level, which would be guaranteed, and be enforceable by law. Women parliamentarians representing organisations like Women in Politics Support Unit (WIPSU) and others lobbied for the adoption of a legislative quota through a constitutional amendment as well as calling for a change in the electoral system to one of proportional representation, which is considerably more favourable to women candidates than the current first-past-the-post (FPTP) or winner-takes-all constituency system. Although the Zimbabwe African National Union-Patriotic Front (ZANU-PF) had adopted a provincial quota it still failed to nominate enough women to satisfy the quota requirements.

The 2005 Zimbabwean elections were conducted in conditions where there was no consensus about the institutions and legal framework governing the elections. Women participated as voters as well as candidates, although some were dissatisfied with both the Constitution and the electoral laws. There were no major constitutional reforms except a few last minute cosmetic reforms to comply with the SADC guidelines. These included the establishment of the Zimbabwe Electoral Commission (ZEC) and the Electoral Court, which came into being two months before the elections.

The changes also included a deliberate restraint on violence, which led observer teams to conclude that the elections were well conducted and peaceful. There was also some opening up of the state broadcasting media a month before the election. Further administrative changes included that all the voting should be done on one day; the absence of mobile polling stations; the use of translucent ballot boxes and 
indelible ink used to prevent people voting twice. None of these administrative changes had any value for women.

Zimbabwean society is polarised ideologically over how to manage the rules of the political game. The election was prejudged as not free and fair by the opposition because of the absence of a level playing field. Women were also divided according to political allegiances, a factor that resulted in tensions when they were organising on issues that affected them as women. Although equal before the law, women were severely limited in the manner in which they engaged with the electoral process by a number of new laws governing the process. Furthermore, thousands of men and women were brutalised by the state-sponsored campaign of terror and political violence that had swept the country since the 2000 parliamentary and 2002 presidential elections. ${ }^{1}$ An increasingly hostile political environment has not only affected women's political participation but has also presented formidable challenges to their perceptions of and relations with the state. This paper reviews the literature on women's perceptions of the state and of gender equality and the environmental and institutional factors that led to the under-participation and under-representation of women in the 2005 elections. The paper concludes by arguing that although women had the right to vote, the prevailing socio-economic and cultural conditions and the lack of a credible and transparent electoral framework since 1980 totally undermined notions of a free and fair election.

\section{Women's Perceptions of the State AND the Struggle FOr Gender EQUALITY}

The role of the state has always been a matter of dispute among feminists. Some see it as a useful tool in furthering women's rights and quality of life, while others see it as an essential element in the development and maintenance of patriarchy and, therefore, as being of no use to women (Craske 1998, p 103). Gendered and feminist analyses reveal that the state is, in almost all cases, male dominated and a masculinist construct (Pettman 1996, p 5). It is not possible to explain state power without explaining women's systematic exclusion from it. Radical feminists have seen the state as inherently patriarchal and simply reflecting the male-dominated nature of society. Socialist feminists see the state as propagating dominant class as well as gender interests and often race and ethnic interests as well. They are therefore more ambivalent towards the state and the possibility of using the state for feminist goals (Pettman 1996, p 10). However, Philips (1995) argues for the 'politics of presence', which enables those who were excluded from politics to engage more directly in political debates. She advocates a straightforward quota as appropriate. Although gender quotas remain controversial they involve significant elements of

1 Most of the violence against the people until the running of the 2005 elections is well documented in human rights reports. One of these is 'Not a level playing field: Zimbabwe's Parliamentary Elections in 2005’. A Human Rights Watch Briefing Paper, 21 March 2005. 
positive action, as shown by the increase of women in legislatures in Mozambique and South Africa. Political equality does carry with it an equal right to be politically present (Philips 1995, p 36).

However, most women in Zimbabwe have engaged with the state in defence of women's practical gender interests rather than keeping completely clear of it and its institutions. Nonetheless, it is possible that there are some women in Zimbabwe who would totally avoid state engagement because they believe that the state and its rulers are illegitimate. The Zimbabwean state is still largely masculinist in its assumption of elite male interests and characteristics as the norm, although there is now a marginalised feminist presence. The state, through its legislation and policies, is still the main organiser of the power relations of gender. Analysts like Catherine MacKinnon (1983) have outlined how the state institutionalises male interests through the law or what has been termed 'state feminism', a system of laws and policies directed at women, mostly protective legislation and reproductive rights such as maternity leave and abortion laws (Waylen 1996, p10). The impact of state action and inaction is gendered, affecting differently men as a group and women as a group. Many of the provisions that are directed at women have been instituted after many years of struggle. For example, the constitutional clause that outlaws gender discrimination came in 1996 after 16 years of struggle, and a National Gender Policy was finally launched only in March 2004.

\section{The War Against Patriarchy}

At independence in 1980, women were, for the first time in the history of the country, officially recognised as an oppressed group and, as such, were the targets of a conscious government policy to change their situation. The power of the state was sought to fight inequality; the state was regarded as a partner in the struggle to abolish inequality. For its part, the Zimbabwean state expressed a strong commitment to the removal of all discrimination against women and the promotion of their participation on equal terms in the social and economic life of the nation. The ruling ZANU-PF party, in accordance with its official Marxist ideology, acknowledged the importance of the woman's role in the struggle for liberation, regarding the emancipation of women as part and parcel of the liberation struggle. Thus, the Ministry of Cooperative and Community Development and Women's Affairs was set up to implement government policy. Teurayi Ropa Mujuru, the then minister of that ministry and now Vice-President of Zimbabwe, summed up government policy as follows:

The policy of this government aims at the transformation of women's status so that they can assume their rightful role in society as participants alongside man on the basis of equality. The department of women's affairs has a programme for the progressive removal of all 
customary, social, economic and legal disabilities that women have suffered in the past and still suffer now.

Africa Report 1983

But as soon as the party and the state began to consolidate and entrench particular positions of power, women were relegated to their old identity almost overnight. From being resistors during the liberation war they were turned into welfare recipients and social dependants. It was 16 years before the Constitution was amended to outlaw gender as a basis for discrimination. However, women continue to be discriminated against as the same Constitution, in s 23, allows discrimination in the areas of 'family law, marriage, divorce, inheritance and customary law'. This constitutional clause, which entrenches customary law, disarms women in their battle against patriarchy. There was no concerted effort by the government to increase the numbers of women in positions of power. The politics of presence was subordinated to mainstream debates about nationalism, nation building and development, which put the emphasis on women's socio-economic status in terms of empowerment, and social development. The deliberate policies designed by the state, the party, donor organisations and non-governmental organisations (NGOs) led to the political and economic disempowerment of women, thereby excluding them from the new post-colonial dispensation (Jirira 1995).

Essof (2005) argues that in these formative years the political will to address gender inequality in Zimbabwe diminished rapidly and was replaced by intensified regulation of women in both the public and the private spheres. Women who organised and demanded the review of customary laws were regarded as proimperialist and anti-nationalist (Essof 2005, p 1). However, legislative changes which sought to give equality to men and women were encouraging. A range of laws was passed in the early 1980s concerning minimum wages for various unskilled occupations, equal pay, maternity leave, divorce, pensions, child maintenance, the legal age of majority (which conferred full legal capacity on every Zimbabwean aged 18 years) and finally, the Constitutional Amendment Act of 1996 outlawed gender discrimination (Zimbabwe Human Development Report 2000, pp 122-124). While the socio-economic status of women improved considerably, their presence in politics rose from 8 per cent to a mere 14 per cent in both the 1990 and 1995 elections.

In terms of keeping up with international trends, Zimbabwe had adopted the UN Convention on the Elimination of All Forms of Discrimination against Women (CEDAW) in 1991. Although the government has ratified CEDAW it has not yet made it fully operational, with s 111B of the Constitution stating:

No international treaty, covenant or agreement signed and ratified by the Zimbabwean government shall form a part of the local laws unless parliament passes a law making the agreement part of the laws of Zimbabwe. 
Thus, women in Zimbabwe cannot approach the courts alleging the infringement of any rights they may have under CEDAW since such rights are not protected under local laws (Gaidzanwa 2004, p 9). So, while organisations such as the Women's Action Group, (WAG) Women and Law in Southern Africa (WILSA), MUSASA, Zimbabwe Women's Lawyers Association, (ZWLA) and Zimbabwe Women's Resource Centre and Network (ZWRCN), to name a few, struggled together for gender justice, the pace of change remained tightly in the grip of the male-dominated state. The Zimbabwean state remained a male exclusive and women remained outside the confines of state power. Those who managed to get into positions of power did so either because of their liberation credentials or because they were related to a man prominent during the struggle. No newcomers managed to penetrate state power. Only one woman, Margaret Dongo, tried to challenge the status quo, breaking away from ZANU-PF and participating in the 1995 elections as an independent. Her reason was her abhorrence of ZANU-PF's intolerant and patriarchal structures. She faced the full wrath of the ZANU-PF state machinery and since then the government has ensured that she remains on the margins of Zimbabwean politics.

\section{Women Opposing the Legitimacy of the State}

It is important to consider the implications for women of authoritarian tendencies and liberalising trends. Women's political gains in the West and in South Africa have, to some extent, been premised upon the existence of liberal democratic assumptions and institutions. We cannot talk of women's participation in politics without examining the impact of repressive policies and violence on their potential for participation. Paradoxically, in Zimbabwe the suppression of political activity within mainstream political institutions has increased the importance of women as political actors through their role within the social movements. However, it should be noted that civil society is not automatically more accommodating of women's claims than are state institutions. As clearly stated by Rai (1996, p 32) 'The state and civil society are both complex terrains fractured, oppressive, threatening, while at the same time providing spaces for struggle and negotiation.'

The failure of the structural adjustment programme in Zimbabwe created conditions for liberalisation, which led to the flourishing of civil society. Because of economic hardships brought about by the Economic Structural Adjustment Programme (ESAP), there were suddenly multiple demands upon the state from a multitude of citizen groups representing different constituencies such as labour, women, war veterans, youth, and others, to deal with issues of the economy, poverty, land reform, corruption, the rule of law and of political exclusion. This new advocacy brought to the fore the failure of political institutions, participation and governance, leading to calls for constitutional reform. At all times women had to put their agenda on the table via male-dominated civil society organisations. For example, in the National Constitutional Assembly (NCA), a network formed in 1997 for 
constitutional reform in Zimbabwe, women had to ruffle a few feathers in order to be recognised and given positions within the network. Women campaigned vigorously for increased female representation on task forces and eight were elected to the 18-member committee in 1999 (Essof 2005, p 4). However, despite the election of a prominent feminist as chairperson of the NCA, the assembly remained maledominated and encouraging a women's agenda involved changing mindsets.

The constitutional reform process was therefore a vital opportunity for women to consolidate their demands for gender justice after many years of engaging unsuccessfully with the state over issues of customary law and culture. As part of the strategy, and in order to have a strong voice on constitutional reform, women formed the Women's Coalition, a network of women's organisations, women activists, academics, and individuals. The coalition organised national and consultative workshops in both rural and urban areas to formulate a women's agenda. As long as the Women's Coalition carried out this work it was regarded as apolitical, but these smooth relations with the state changed dramatically when, together with the NCA, it campaigned successfully for a 'No' vote in the Constitutional Referendum held in February 2000. It was as if civil society had declared war on the ZANU-PF government. Most of the 'No'-vote gatherings were violently dispersed by police.

The NCA and the Women's Coalition argued that the government-orchestrated draft constitution would again firmly entrench the powers of the executive president. The women campaigned for a 'No' vote on the grounds that the draft constitution did not guarantee women's rights to equal social and economic standing, including healthcare and education, and it did not uphold their right not to experience violence. Furthermore it did not offer equal political representation or protect women from discriminatory cultural practices and it generally ignored the wishes of the Zimbabwean people (Essof 2005, p 5).

The surprise rejection of the draft constitution, a victory for the opposition, civil society and women's groups, shocked the government and led to a campaign of violence that left 31 people dead in the lead-up to the 2000 parliamentary elections. State-sponsored violence against all political opponents and women who opposed ZANU-PF presented a real threat to women, many of whom were beaten and assaulted because they supported the opposition Movement for Democratic Change (MDC). In the face of such violence it was difficult to mobilise women candidates to stand in the 2000 parliamentary elections and the need for opponents who could stand up to the threats of violence meant that women were left out of the nomination process. The newly formed MDC, which espoused democratic norms, proved a disappointment in the area of gender equity. Equity for women was not a central plank of the party's platform and often disappeared from the political terrain altogether. The major issue for the MDC was unseating ZANU-PF from government and the politics of power became the major driving force rather than the complete democratisation of the political system and the establishment of a more democratic and inclusive political environment. 
As women have positioned themselves in opposition to the state the state has not hesitated to unleash its violent arms and has also rewarded those who are accommodating and loyal to state policies. For example, in February 2004 three women were appointed to powerful positions in the public service commission, the comptroller and the auditor general's office (Herald 26 February 2004) but those who demonstrated against the prevailing political economic environment were beaten and arrested. Women In Zimbabwe Arise (WOZA) has demonstrated against declining standards of living, the lack of good governance and the state-sponsored violence. Its members have protested as women, some with children on their backs, who want to see the society in which they live embrace more democratic ways of dealing with the governance and economic crisis. In the run-up to the March 2005 elections demonstrators were beaten and arrested at least four times (Amnesty International News 4 April 2005).

With this history of struggle, exclusion, and persecution, the women of Zimbabwe found themselves at the dawn of the 2005 elections in a situation in which nothing had substantially changed. Their relationship with the state remained problematic and they had no united front. Although the election days were peaceful the whole process was haunted by repressive laws and no provision was made to give women better access to power.

The two major parties, ZANU-PF and the MDC, remain the central cause of women's lack of progress. ZANU-PF has consistently marginalised women since 1980. The MDC is no different - it is patriarchal and the pace of women's advancement, even in party ranks, depends on the goodwill of the male leaders. It failed to nominate many more women candidates than did ZANU-PF in both the 2000 and the 2005 elections. The women in both parties operate within a framework defined by men, hence their failure to push for a national women's agenda.

\section{Women's Participation in the ZimbabWe 2005 Elections}

The 2005 elections did not provide a legislative and political environment conducive to ensuring the full and unhindered participation of women. The initial threats from the opposition that it would not participate unless a level playing field had been established affected the preparedness of women in the opposition. Both ZANU$\mathrm{PF}$ and the MDC did very little to ensure women's increased candidature or representation, save for the ZANU-PF provincial quota, which did not meet the 30 per cent quota called for by the SADC declaration on gender and development.

\section{A Gender Insensitive Legal and Electoral Framework}

A country's constitutional and legal framework should guarantee equal civil and political rights to every person on a non-discriminatory basis. However, s 23 of Zimbabwe's Constitution, which outlaws discrimination on any grounds, whether sex, race or religion, has a clause permitting discrimination on the grounds of family 
law, marriage, divorce, inheritance and customary law. This clause has entrenched patriarchy and allowed women not to be treated as equal citizens under customary law. Furthermore, while Zimbabwe is a signatory to CEDAW, the law has not been approved by Parliament as part of the local law of Zimbabwe. So women cannot look to CEDAW for redress in the event of infringements of their rights (Gaidzanwa 2004, p 9).

Furthermore, an amendment to the Citizenship Act, which came into effect in 2001, by which citizens of Zimbabwe who also hold foreign citizenship had to renounce their foreign citizenship and claim Zimbabwean citizenship within six months has affected women's right to vote. Although there has been insufficient research into how many people were deprived of their citizenship, because the amendment was publicised largely in the urban areas, many women in rural areas (where about 60 per cent of households are headed by women) were disenfranchised. The system for renouncing one citizenship and applying for another was laborious and expensive and many rural women could not afford it. It is believed that the majority of those affected were farm workers and rural dwellers born in Zimbabwe's neighbouring countries or whose parents were born in those countries (Gaidzanwa 2004, p 10).

Women's political participation is also affected by Zimbabwe's electoral laws, which are an important factor in determining the number of women elected to legislative office. It is widely acknowledged that electoral systems are not gender neutral. Women fare very poorly in a FPTP system unless there are special measures for their inclusion. Research in the SADC region, where 8 of the 13 countries use the FPTP system has shown that the system is stacked against women (Morna 2005, $\mathrm{p} 22$ ). A number of reasons have been put forward for this but it appears that the biggest problem for women is winning a nomination. Membership of political parties is a strongly gendered process based on the availability of time, energy, resources and skills to participate in the public domain (Gaidzanwa 2004, p 11). Very few women can find the time and resources to devote to party activities as well as to the gendered roles of childbearing and caring and domestic responsibilities. As Morna (2005) argues most of the political parties are 'old-boy networks' which maintain firm control of their candidates and know that selecting a woman means dropping one of 'their own'. Furthermore, most women are regarded as lacking political clout, especially when the stakes are high, as in the 2000 elections when parties preferred to place highly competitive candidates, who were mostly men.

Zimbabwe's electoral system contains no affirmative action measures and the election of women has been left to chance. Table 1 illustrates the 'slow climb' to power of women in Zimbabwe since 1980 and the persistent inequalities in gender representation.

The largest women's presence in Parliament was in the period between 1990 and 2000 when they were there not because of any special measures but because of the 'benevolence' of male party leaders. The years 1990 and 1995 were the most 
comfortable election years for ZANU-PF, with no serious threats from a weak opposition. The Zimbabwe African People's Union (ZAPU), which was the only viable opposition, had been swallowed up in a Unity Accord in 1987 in the hope of instituting a one-party state in 1990.

Table 1

Women in the Legislature 1980-2005

\begin{tabular}{|l|r|r|r|r|r|c|}
\hline Year & $\mathbf{1 9 8 0}$ & $\mathbf{1 9 8 5}$ & $\mathbf{1 9 9 0}$ & $\mathbf{1 9 9 5}$ & $\mathbf{2 0 0 0}$ & $\mathbf{2 0 0 5}$ \\
\hline Total seats & 100 & 100 & 150 & 150 & 150 & 150 \\
\hline Women & 9 & 8 & 21 & 22 & 14 & $24^{*}$ \\
\hline Men & 91 & 92 & 129 & 128 & 136 & 126 \\
\hline$\%$ women & $\mathbf{9} \%$ & $\mathbf{8} \%$ & $\mathbf{1 4} \%$ & $\mathbf{1 4 . 1} \%$ & $\mathbf{9 . 3} \%$ & $\mathbf{1 6} \%$ \\
\hline
\end{tabular}

Adapted from Gaidzanwa 2004, p 45

* 20 women were elected directly to the legislature, 2 were appointed as governors by the president and 2 were appointed as non-constituency MPs, bringing the total number of women parliamentarians to 24 .

To begin with, the feeble opposition parties that would contest the elections - the Zimbabwe Unity Movement (ZUM), formed in 1990, and the United Parties (formally Bishop Abel Muzorewa's UANC) - boycotted the elections, leaving ZANU-PF the clear winner. However Krieger (2005), in a study of ZANU-PF strategies in general elections since 1980, exposes startling similarities between the tactics used in the 1980s and the ruling party's discourse and coercive mechanisms in the 2000 and 2002 elections. Krieger (2005, p 31) asserts that the intensity and degree of orchestration of ruling party violence in 1985 and 2000 stand out sharply from the violence in the 1990 and 1995 elections. This clearly puts the 1990 and 1995 elections in a category of their own in terms of electoral environment and the level of violence and intimidation and also the level of women's participation. The slight decline and the slight increase in women's numbers reflect the change in electoral dynamics and environment within which ZANU-PF has operated since 1980.

To further illustrate Zimbabwe's lack of commitment to gender equality since 1990, s 31h (c2) of the Constitution allows the president to appoint members of Parliament according to 38 of the Constitution, which stipulates the composition of Parliament. The president may appoint 30 of the 150 members of Parliament. At least eight of these appointed members must be provincial governors, at least ten must be chiefs elected in accordance with the electoral law and twelve are nonconstituency members. The president has never used this prerogative to increase the number of women - in the 2005 elections he appointed two women and six 
men as governors. Two women were appointed among the 12 non-constituency MPs, bringing to 24 the total number of women represented in the legislature.

\section{A Gendered Participative Political Environment}

Political participation extends beyond parties and their organisational structures. Women in unstable and violent political environments such as that in Zimbabwe are often active participants in civil society, which is an entry point to the political arena. However in Zimbabwe the erosion of the democratic space through the passage of repressive laws has defined the rate and level of women's participation in the political process and in the 2005 elections. The Public Order and Security Act (POSA) imposes severe restrictions on the ability of citizens to meet and assemble freely. Police permission is required for a public meeting/rally of more than three people. Police use the powers given to them under POSA on a discriminatory and partisan basis.

Furthermore, the opportunity for voters, specifically women, to access the information necessary to make an informed choice at the ballot box is curtailed by the absence of a free media environment. Restrictions on a free press and the flagrant lack of equal access to the state media preclude the free flow of information and ideas especially in the rural areas, where most poor women live. Furthermore, provisions contained in the Access to Information and Protection of Privacy Act (AIPPA) violate Zimbabweans' constitutional right to freedom of speech. This piece of legislation was promulgated in April 2002 just after the presidential election. No attempt has been made to repeal sections which blatantly infringe people's basic right to receive and impart information of their choice. In terms of AIPPA all journalists and media organisations have to register with the Media and Information Council (MIC), a partisan body given wide ranging powers under the Act to decide which newspapers may operate and which journalists may practise their profession. A number of local as well as foreign journalists have been arrested in terms of AIPPA while not a single journalist working for the state-controlled media has ever been arrested, confirming the partisan nature of the police force. The ZANU-PF Government, after restricting certain freedoms and civil liberties, went on to try to curb civil society activism by passing the Non-Governmental Organisations (NGO) Act on 9 December 2004, although the President has not yet signed the Act to bring it into force.

The Act, which seeks to ban all foreign-funded NGOs in the areas of governance, threatens the livelihood of many governance related NGOs, most of which are women's entry point into political activities. It would effectively curtail women's ability to use the platforms provided by civil society to participate in the political process and influence political developments and government policy. One thing it did achieve was to cause NGOs which would otherwise have supported electoral activities related to the 2005 elections to waste valuable time strategising about how they would survive if the Act was passed, with some contemplating 
relocating to other countries. If the Act ever does become law it will mean that the vast majority of women' voices will be silenced, as most women are found in NGOs rather that in political parties and government structures.

\section{Women's Participation as CANDidates In the 2005 Elections}

Women's participation in politics generally is affected by a number of factors, ranging from personal to institutional and structural. However, in Zimbabwe, the hostile political environment is an additional factor. Since the disputed 2000 and 2002 elections the country has descended into political violence and lawlessness. Through the use of repressive legislation the citizen's rights to freedom of expression and association and assembly in many parts of the country have been significantly restricted. Opposition party members and ordinary citizens have been intimidated by ruling party supporters and officials, war veterans and the youth militia. One of the most pervasive problems for women politicians is funding. Running a campaign, starting with the primary election, is an expensive venture.

These problems clearly illustrate that the political and economic environment were not conducive to the holding of a free and fair election. Nonetheless, 58 women were among the 272 candidates who entered the electoral race in spite of the odds stacked against them. In 2000, 55 women stood and only 14 were elected. In 2005 ZANU-PF fielded 30 women among its 120 candidates, the MDC 18 out of 120, ZANU (Ndonga), another long-time opposition party, fielded 8 women and 2 stood as independents (WIPSU 2005). It was clear that the SADC 30 per cent was not going to be met. However, apart from the elevation of Joice Mujuru, a former minister, to the position of vice-president, the issue of women's presence was sidelined by the more pressing issues of land and the economy.

ZANU-PF's decision to adopt a 30 per cent provincial quota for women candidates is said to have been the result of intense lobbying by the party's women's league. The pressure to meet the SADC minimum also came from the women's movement (WIPSU 2005). However, within the party the implementation of the quota faced a number of problems with allegations that some of the women were imposed as candidates. Some men also felt that their constituencies were designated women's constituencies. In the end only 30 women candidates from ZANU-PF stood. In their analysis of the participation of women WIPSU believes that the success or failure of women candidates depended on the constituencies they contested. All the ZANU-PF women in urban constituencies lost in the traditional MDC support bases. Of the six women who won seats for the MDC, five won in urban constituencies and one in Matebeleland, a rural constituency. Twenty women contested rural constituencies for ZANU-PF, 14 won, while the ten who contested urban constituencies all lost. WIPSU concludes that if ZANU-PF had fielded more women in rural constituencies and the MDC had fielded more in the urban areas more women would have won across the country. In the end, ZANU-PF had 14 women MPs and the MDC 6 . The women of ZANU (Ndonga) and the independents 
did not win any seats. There was a clear lack of commitment by both parties to ensure women's increased candidature and ultimately their representation.

\section{A SKewed Media Environment}

Neither the media environment nor the political environment has been conducive to gender mainstreaming since 1980. AIPPA, which regulates the print media, ignores gender issues on two levels - its technical provisions and its overall effect on the right to information and expression. The Media Institute for Southern Africa (MISA) argues that the Media Information Council (MIC) is male dominated (MISA 2005). The use of AIPPA to close four daily newspapers - The Daily News, The Daily News On Sunday, The Tribune and the Weekly Times - deprived Zimbabweans, more specifically women, who are already marginalised in relation to acquiring information, of alternative sources of information.

On 16 February 2005 the government gazetted regulations permitting opposition parties reasonable access to the state-controlled electronic media. These regulations were introduced too late to have any meaningful impact, especially for the opposition and women candidates, who are rarely newsmakers. Most of the news coverage on national television was reported by MISA to have been biased in favour of the ruling party.

MISA surveyed the coverage of women in the media (three print media houses and television) from 1 March to 31 March 2005. Within this period women candidates accounted for only 17 per cent of the news (MISA 2005). Even on 8 March, International Women's Day, there was no more coverage of women candidates than at any other time. None of the media gave women more than 19 per cent coverage. Furthermore, in all the stories monitored, women were identified as 'mother' or 'wife of'. According to MISA most of the actions and opinions reported are those of men - of the 403 election stories monitored only 37 (9\%) had women at the centre of the story. Making space for women candidates during the election campaign was a non-issue although there were calls by SADC for equitable access to the state media across the socio-political and economic divide.

\section{DisCRIMINATORY VOTER Registration}

The accuracy of the voters' rolls and the inclusiveness of the lists are central elements in ensuring women's full participation in the electoral process. But the voters' roll in Zimbabwe is alleged to have been in a shambles since 1985. There have been incidences of the inclusion of deceased persons, misspelt names, voters slotted into incorrect constituencies and members of the same household allocated to different constituencies. This has resulted in the disenfranchisement of potential voters (ZESN 2005). In the 2005 elections a series of new criteria for voter registration were instituted. For urban dwellers these included a lodger's card or rate bills in the voter's name as proof of residence. Given the patriarchal nature of Zimbabwean 
society most of the documents bearing proof of residence have the man's name on them. While there is no evidence to show how many women were affected by these new criteria, there is no doubt that a number of women might not have registered because they did not have such documents.

The automatic change of citizenship to that of a woman's husband, which was carried out by the registry office without alerting the affected woman, might have meant that women had identity documents which did not match those on the voters' roll. The MDC alleges that voter registration was carried out in a discriminatory and secretive manner with the aim of securing political advantage for the ruling party. The whole registration process carried out in May and July 2004 was barely publicised in the urban areas, which are the opposition's stronghold, with information targeted at the rural areas, the stronghold of ZANUPF (MDC Report April 2005, p 11). Women who were opposition supporters were doubly discriminated against. The ZESN report confirms some of the opposition's claims, observing that voter registration was the weak link in the electoral process. There was insufficient publicity about the process, which was not supervised by an independent electoral body. Access was only permitted to the voters' roll late in the process and was costly (ZESN Report 2005, p 9). The opposition MDC, dissatisfied with the registration process, alleges that the voters' roll 'was the government's principal vehicle for electoral fraud; an inflated voters' roll created tremendous capacity for ballot stuffing' (MDC Report April 2005, p 12).

\section{INADEQUATE Voter EDUCATION}

Voter education can be a critical factor in enhancing women's participation in elections, particularly if emphasis is placed on the right of women to be elected. It also helps women to make more informed and responsible choices. Voter education should include information on voting rights, the political system and candidates as well as information about where and how to vote.

In the 2005 elections the role of non-state actors, especially NGOs, the organisations that are able reach more women because of their grassroots membership, was restricted because of the NGO Bill. The Zimbabwe Election Commission started its voter education campaign late and with only a limited reach (ZESN Report 2005). Voter education by non-partisan bodies would have been crucial in the rural areas, where there was manipulation of food aid and where traditional leaders were used to coerce the electorate. Numerous reports from independent media organisations recorded how ruling-party officials denied food aid to those suspected of supporting the MDC (MDC Report 2005, p 23). Since women are far more vulnerable to threats of a lack of food and also far less politically informed, some, who would have voted for the MDC, may have stayed away from the polls, fearing that their choice might be made public. Targeted voter education would have helped to allay some of these fears and enhance women's participation. 


\section{CONCLUSION}

The political environment in Zimbabwe, which values power struggles, remains one of the major obstacles to women's participation and representation. For the majority of Zimbabwean women the playing field is far from level and considerable societal and cultural prejudices are still attached to being a woman in politics and promoting women's causes. In addition the electoral system was a major obstacle to the full participation of women in the 2005 elections. The system in its present form does not facilitate higher levels of representation of women.

The political parties appear to have no clear policies on gender equality and have not developed a systematic approach to it. It is the male-dominated political parties that will have to create the avenues for women's presence. Women in Zimbabwe should be able to demand not just a presence but a broader democratic process that guarantees liberties together with broader political representation and political space to demand social and economic rights, better living standards and basic services. Unless major changes occur in Zimbabwe's political institutions and its constitutional and legal framework persistent gender inequalities will remain a foregone conclusion. The struggle for the politics of presence should go together with the overall democratisation of Zimbabwean politics.

\section{- REFERENCES -}

\section{Books and Journals}

Craske, N. 1998. 'Remasculinisation and The Neoliberal State in Latin America'. In V Randall \& G Waylen (eds). Gender Politics and the State. London: Routledge. Essof, S. 2005. 'She-murenga: Challenges, Opportunities and setbacks of the Women's Movement in Zimbabwe'. Feminist Africa 4 http:// www.feministafrica.org/04-2005/essof.html

Gaidzanwa, R. 2004. Gender, Women and Electoral Politics in Zimbabwe. EISA Research Report No 8.

Jirira, J O. 1995. 'Gender Politics and Democracy'. SAFERE 1(2).

Krieger, Norma. 2005. 'ZANU PF Strategies in General Elections, 1980-2000:

Discourse and Coercion'. African Affairs 104(414).

MacKinnon, C. 1983. 'Feminism, Marxism, Method and the State: Towards a Feminist Jurisprudence'. Signs 8(2).

Morna, C L.2005. Missing the Mark? Audit of the SADC Declaration on Gender and Development: Women in Decision Making. Gender Links, International IDEA.

Randall, V \& G Waylen (eds). 1998. Gender, Politics and the State. London and New York: Routledge.

Rai, S. 1996. 'Women and The State in the Third World'. In H Afsher (ed). Women and Politics in the Third World. London and New York: Routledge.

Randall, V. 1998. 'Gender and Power: Women Engage the State'. In V Randall \& G Waylen (eds). Gender Politics and the State. London and New York: Routledge. 
Pettman, J J. 1996. Worlding Women, A Feminist International Politics. London and New York: Routledge.

Philips, A. 1995. The Politics of Presence. Oxford: Clarendon Press.

Waylen, G. 1996. ' Analysing women in the Politics of the Third World'. In H Afsher (ed). Women and Politics in the Third World. London and New York, Routledge

\section{Reports}

Human Development Report. 2000. Zimbabwe Governance. Harare: UNDP.

MISA-Zimbabwe. 2005. So Many Rivers to Cross: MISA-Zimbabwe Report on the Media Potrayal of Female Political Candidates in the Zimbabwe March 2005 Parliamentary Elections.

Human Rights Watch. 2005. Not a Level Playing Field: Zimbabwe's Parliamentary Elections in 2005. A Human Rights Watch Briefing Paper, 21 March.

WIPSU. 2005. An Analysis on Women Candidates' Participation in the 2005 Parliamentary Elections. Women in Politics Support Unit, April.

Zimbabwe Election Support Network (ZESN). 2005. Report on the Zimbabwe 2005 General Elections 31 March 2005.

MDC. 2005. Stolen. The Will of the Zimbabwean People Denied Again. MDC Report on the March 2005 Parliamentary Elections, 12 April.

Constitution of Zimbabwe Revised Edition. 1996. Harare: Government Printers. 